The Third Pole: Journal of Geography

Vol. 20 - 21: 1-8, 2021

DOI: https://doi.org/10.3126/ttp.v21i01.41612

Department of Geography Education,

Central Department of Education, T.U., Kathmandu, Nepal

\title{
TEACHERS' PERCEPTION OF THE REALITY OF GEOGRAPHY EDUCATION IN NEPAL
}

\section{Tara Prasad Awasthi ${ }^{1}$}

\section{Abstract}

This paper analyzes the teachers' perceptions of the reality of geography education in Nepal. The term teachers' perceptions refer to a how teachers attach meaning to experience in the realities of geography education. It is based teachers involved in teaching geography at the campus university level in the Kathmandu Valley. It looks at the contribution that geography can make in the education of young people and the flourishing of the subject of geography in Nepal. For this purpose, a descriptive survey method was employed. The information used in this paper was obtained through questionnaires, focus group discussions, and observation. A purposive sampling technique was employed to select teachers. The results indicated that input is a dominant factor for the quality of geography education. Other factors like government policy, student interests, job markets, and perceptions of people, planners, policymakers, and administrators are also indicators that received the lowest rating of geography education in the study area. The findings show that the relationship between policies and practices of teaching-learning processes influenced the teachers' perception of geography education.

Keywords: Teachers' perception, school curriculum, government policy, job market, educational reform

\section{Introduction}

Geography is a valuable subject resource for the school curriculum. It requires more 'imparting knowledge' in the intellectual engagement with the discipline so that its perspectives and insights are applied in an educational setting (Lambert \& Morgan, 2010). Geography has meant different things, different people at times and places (Livingston, 1992). Geography explores the relationship between the earth and its peoples through

1 Awasthi is a Lecturer, Department of Geography Education, Tribhuvan University, Kathmandu Nepal. Email: star2012awasthi@gmail.com 
the study of place, space, and environment. It is the mechanism of place, people and environment. Therefore, that geography is the science of place and space. Geographers ask where things are located on the surface of the earth why they are located, how places differ from one another, and how people interact with the environment. Geographers also study the linkage between human activities and natural systems. They are active in studying global warming, desertification, loss of biodiversity, climate change, and flooding (http//www.esri.com, 2018). Lambert \& Morgan (2010) argued that geography is a discipline that involves creating concepts in response to changes like the world. School geography teaches about significant social and material changes such as economic shift, environmental transformations, and cultural development, it offers students frameworks for understanding and evaluating these ideas through developed in geography, and its implications for teaching geography (p.3).

In the western world, the scientific study of geography began only during the nineteenth century after the philosopher like Kant, Humboldt, Ritter, Peschel, and Ratzel defined the scope and content of the subject and developed scientific geography (Amatya, 1974). In the nineteenth and early twentieth century, the main body of geographers employed the concept of environmental determinism. The approach of environmental determinism was somewhat derailed after the contribution on possibilism by the French geographers. The development of geography cannot be separated from the development in social science as a whole and the debate on the importance of science versus arts or philosophy. In the late 1950s and 1960s, social science began to develop as a science. The positivist approach that led to the concept of objective knowledge was gaining importance. In the course of development, geography has embraced an interdisciplinary approach in research as well as integrates both physical and social sciences (Adhikari, 2003).

At present, geography commonly referred to as the study of the environment and man's changing relationship with it. Like most other social science discipline, it is dynamic and over the last few decades, changes have taken place in both the nature and scope of the discipline (Subedi and Joshi, 1997)

In Nepal, geography was introduced much later. In 1901, Jaya Prithvi Bahadur Singh was first to write geography book in Nepal (Pandey, 1998; Awasthi, 2013). However, the discipline became more systematic and organized only after the formation of school leaving certificate examination Board in 1934 and geography was included in the school curricula (Jnawali, 2001). At the university level, Faculties of Humanities and Social sciences and Education have introduced geography the first has given priority on content and the latter focusing on both content and pedagogy. In spite of over a half century long history of geography in Nepal it has several debates and dilemmas concerning on 
its disciplinary expectations of the society (Subedi \& joshi,1997)curricular issues at vertical linkages of courses from school to teaching methods and materials (Panday, 1998; Jnawali, 2001).

Over the years, geography at the school level has gone through several difficulties. With the national education system plan (NESP) in 1972, the identity of optional category (Subedi \& Joshi, 1997). Geography is being included as a part of social studies in the secondary levels curriculum where the content of geography is limited. Meantime, geography is losing its popularity in both school and higher level. Therefore, geography is not remaining as a popular subject among young students. At present, the place of geography in schools and universities in Nepal seems to be declining. In this context, this paper aims to analyze the teachers' perceptions' of + the reality of geography and the reasons for the decline in geography in the case of Kathmandu Valley.

\section{Method and Materials}

This paper is primarily based on primary and secondary data sources. Primary data were collected from field observation, questionnaire, in-depth interview; key informant interview and focus group discussion. In this study, five campuses teaching geography at university level have purposefully selected for detailed study. The senior geographers of geography were selected as respondents from the University Campus, Tri-Chandra campus, Padma-Kanya Campus, Patan Campus and Ratna Rajya Campus) of Kathmandu valley. The in-depth interviews were employed to collect teachers' feelings, narratives, perceptions, truth and reality on the geography education in Nepal. Note taking is a major tool used to obtain and record information. Their views and perceptions were checked and verified. These data were transcribed and both descriptive and analytical methods used to prepare this paper.

\section{Results and Discussion}

Geography Education in Nepal: In Nepal, geography placed an organized subject after the establishment of the SLC board in 1934. Indeed, teaching geography at the school level was started in 1901 (Koirala, 2008), but the subject has been taught informally since Vedic Periods (Panday, 1998; Subedi, 2014). Teaching geography was first started at TriChandra College in 1947 at the Intermediate level, then it was increasing 28 constituent and six affiliated campuses in 2013(Subedi, 2014). It was started at the master level from University Campus in 1961 and Prithi Narayan Campus Pokhara in 1978 (Adhikarai, 2010; Subedi, 2014). The Faculty of Education (FoE) has also introduced a Master's Degree in Geography Education in 1992. However, the Department of Geography Education was established in 1994 (Panday, 2009; Subedi, 2014). 
On the eve of the ongoing educational reform process, this reform has begun with the establishment of the College of Education in 1913, and the endorsement of the New Educational System Plan (NESP) in 1971. Nowadays, education has given pace at the center of Nepalese development strategies since 1992. Subedi and Joshi (1997) argued that geography outlined to bring it in both academia and research that addressed the vigorous needs of nations from within the discipline. The period up to 1960 to 1980 s witnessed geographical research in Nepal that covers broader issues of agricultural land use, spatial pattern and processes of services area studies, regional planning and environmental studies (Koirala, 2008). However, Awasthi (2013) claimed that study and research on geography is getting weaker as the government has cut the budget for research from the university level and study from the school level.

Reality on Geography education: Geography, like all dynamic areas of disciplinary thought, is in a constant state of becoming geography is a discipline. It involves creating concepts in response to changes like the world (Lambert \& Morgan, 2010 p. xi). In Nepal, the development of geography education at the university level appears to have reached its peak in the 1990s. However, the development of geography education at the school levels seems to have reached its peak before introduction of National Education System Plan (NESP) 91971) and after NESP seems to have traced back to the place and importance of the subject from school level curriculum. It is mainly depends on the context and the agreement of the national policies. For example, the neoliberal economic policy of Nepal has embellished in the fields of education, health, banking and finance since 1990. In this incident, many subjects including geography downfall from the university-level cannot compete in the market. Meantime, geography is being included as a part of social studies in the secondary level curriculum where the content of geography is limited. Thus, it has lost its popularity in both school and higher level. At that time, Lambert and Morgan (2010) seek to outline some of the important shifts in the latest phase of capitalist modernization and explore different interpretations of these changes (p. 16).

On the other hand, Geographic Information System (GIS), Remote Sensing (RS) and Global Positioning System (GPS) have taught on the subject of geography since 2000. However, the inability to integrate this technology with the school-level curriculum, and the needs of the country seems to have diminished the place and importance of geography education in Nepal. As the present time based on information and communication technology, if GIS, RS, GPS technology and geography of tourism can be integrated into the school level curriculum, the future of geography will be bright. The integration of rapidly evolving technology in curriculum that and creates job opportunities for innovative teaching and learning. It helps to breakthroughs in a multitude of disciplines. 
Teacher Perceptions on the Reality of Geography Education: Teachers' perceptions have an enormous effect on the successful implementation of geography education at different levels. The geography curriculum designed with covering geographic concepts, themes and traditions for teaching and learning. The result reveals that the perception of teachers' toward geography education and its successful implementation depend on the quality of curriculum, themes and new approaches that creates several jobs in the markets. The findings indicates that the effectiveness of geography education requires a strong link between teacher professional development and quality-especially in areas of teachers' belief, understanding and practices, students learning and on the implementation of educational reforms. Teachers' professional development should focus on handling GIS technology and use of ICT in the improvement of the quality of geography education.

One of the key persons from the University Campus said that:

'Geography students are coming to the university campus, but the enrollment rate is declining compared to previous years. There is not a shortage of students in our department. The student number declined due to the phase-out of intermediate level from Tribhuvan University. The majority of schools have not given pace to geography curriculum in the school subject. Thus, at least fifty marks geography subject taught compulsorily at the secondary level to strengthen geography education in Nepal'. He further stated that 'we have been designing a curriculum covering a scope to convince students. We became individual geographers, but a bold institutional decision requires credential building regarding geography education in contemporary societies. However, a lack of financial resources and TU has also treated us as stepmothers to strengthen our efforts in national development.'

The next key person points out:

'The institutional and subject issues are two major causes for declining the legacy of geography education from both schools and university levels. We forgot the core of geography, and we are running toward the slogans of Non-governmental Organization' (NGO) themes and dollars. However, we are unable to address the voice of wider societies in the core of geography subject. He further stated that there is not any readymade answer. It requires coordination between institutional and subject experts to draw new approaches to geography that support national development'.

A senior teacher from the same campus said that:

'Geography education has not addressed the needs of the market. Quality education is a fundamental prerequisite to hold jobs; however, our students become jobless. As a result, it cannot fulfill the dream of parents when their successors hold the 
job after having a degree. Job placement is the main objective of the majority of Nepalese students. However, both government policy and our curricular structure are inappropriate. We have only given pace to theoretical aspects in the curriculum and less priority to practice including information and communication technology (ICT).

An informant from the same campus reported that:

'Our curriculum focuses on the human aspect of geography, and less priority has given to physical geography. Because of a lack of research funds and institutional support, the curriculum has also enabled to link teaching and research. Dr.H. Gurung has made his identity as a regional planner for national development. He has introduced the concept of growth poles, service centers, and growth centers. However, the holistic nature of geography decreases its scope of national planning. He argues that the adoption of GIS, GPS, RS geospatial technologies, non-spatial technology and tourism geography have created a job-oriented curriculum that furthering the scope of geography in the competitive markets'.

The next informant said that:

'doctor's engineers and English exports can't recognize the state and the development of the state is also impossible in the hands of those who couldn't understand the nation that is why geography is necessary for the welfare of the state. To produce good citizens, cultural and moral education should be a compulsory subject at the school level.'

A respondent from Tri-Chandra Campus said that:

'There is no job in the market. Geography has not been considered a job-oriented subject as a result it is not included in the core of school level curriculum. The state did not think about the contribution of geography and geographers in the national development. Dr. Hark Gurung had contributed to Nepal as a geographer. However, other experts in geography remain a shadow of the decision-making. The state could not understand the significance of geography and geographers. For example, the state has accomplished the division of federal states without the contribution of geographers. The government has not given pace to geographers in restructuring local government (Municipality and Rural Municipality). A geographer can do all these tasks by employing GIS software successfully. However, we cannot show our legacy in the national development.'

A senior teacher from Padma Kanya Campus reported that:

'how do we get students in Bachelors and Master levels when the grass roots have cut down? What is the source of students? Is our country does not need 
workers trained in geography? The state and we geographers carefully think these questions to reach any decisions. In my opinion, without geographic knowledge, a person does not make a proper understanding of the resources available in a country, such as land, water, agriculture, forest, and aesthetic resources. It is very difficult to plan for resource mobilization. He has given importance to the subject committee to create pace in the market. He claims that he was nominated as a member of the subject committee. But his tenure was over without even participating in a single meeting.'

Another informant from the same campus stated that:

'we make a blunder mistake from the school level. We have not made a practical curriculum to address the lives and livelihoods of people living in different environments. It is not a curricular policy problem. However, the problem is of foreign experts' domination in policy formulation. For example, without proper infrastructure facilities, we introduced a semester system with the decisions of the World Bank. Thus, we are going to lose our identity as a geographer'.

\section{A senior teacher from Ratna Rajya Campus told that:}

'the subject of geography cannot create a job in the market. Due to the lack of contextual curricula, and the state's discriminatory policies have not addressed the needs of learners and the nation. Thus, we could not be convincing the scope of geography in both public and media'.

\section{A senior teacher from Patan Campus told that:}

'the scope of geography subject is a very wider than other subjects. However, the subject of geography education enabled creating a market compared to other subjects like Rural Development, Population education, sociology, and so on. We should develop research and student-oriented curricula to address pedagogical needs and educational research'.

\section{Conclusion}

The paper concludes that teachers' perceptions of the reality of geography education are very essential to strengthen the legacy of discipline in research and teaching learning. The findings show that geography education in Nepal remains in crisis at both the school and higher levels. The subject has not addressed the needs of job markets in the neoliberal and post-modern age. New geographic approaches and methodologies are required for credential building. The adaption of geospatial technologies such as GIS, RS, GPS and geography of tourism opens new horizons of geography in the changing society. Thus, we should focus on quality products by integrating ICT with geographic knowledge, skills, and understanding. 


\section{References}

Adhikari, J. (2003). Geographical education and studies in Nepal. Unpublished Seminar Paper. Kathmandu, pp.1-35.

Amatya, S. L. (1974). Geography in Nepal. In Prayag Raj Sharma (ed.), Social science in Nepal. Kathmandu:. Institute of Nepal and Asian studies, pp. 1-17.

Awasthi, T. P. (2013). Geography study in Crisis. Mini Research Report. Research Division: Rectors office. Tribhuvan University, Kirtipur, pp. 1- 43.

Bernard, H.R. (1995). Research methods in anthropology: Qualitative and quantitative approaches. London: Altamira.

Johnston, R.J. (1996). Geography and geographers: Anglo-American human geography since 1945. London: Arnold

Jnawali, D. (2001). Nepalma bhoogolshiksha: pathyakram, pathyapustakrashikshan (Geography Education in Nepal: curriculum, textbooks and teaching). Kathmandu: Center for Educational Innovation and Research (CEIR). 1 (1), pp.117-129.

http//www.esri.com, (2018)

Khatiwada, S. P. (2019). Status and barriers of classroom-based student assessment practices in geography at secondary level in Nepal. Nepalese journal of educational studies. Kathmandu: Central Department of Education.

Kitchen, R. \& Tate, N. J. (2000). Conduction research in human geography: Theory methodology and practice. London: Pearson Education Limited.

Koirala, H. L. (2008). Geography in crisis: Is geography in Nepal an exception?. In Subedi, B. P. (ed.), The Geographical Journal of Nepal. Kathmandu: Central Department of Geography, pp31-44.

Lambert, D. \& Morgan. J. (2010). Teaching geography 11-18: A conceptual approach. England: Open University Press/ McGraw-Hill Education

Livingston, D. (1992). A brief history of geography. In Rogers, A., Vile, H. and Goudie, A. (eds.), The students companion to Geography. Oxford: Blackwell.

Panday, R. K. (1998). Pioneers of Nepalese geography: Geography and geographers in Nepal. Kathmandu: Center for Nepalese Geography, pp.138.

Subedi, B.P. and Joshi. B. D. (1997). About geography in Nepal: An outline for discussion. In Katry, P. K. (ed.), Social sciences in Nepal: Some thoughts and search for direction. Kathmandu: Center for Nepal and Asian Studies, pp. 90-112.

Subedi B.P. (2005). A glimpse of geographic research in Nepal: review and reflection. In Subedi, B. P. and Poudel P. C. (eds.), Geography and geographers work in Nepal: reflections on mountain environment and human activities. Kathmandu: Central Department of Geography, Nepal geographical society and NCCR north-south, pp. 85-103.

Subedi, B. P. \& Poudel, P. C. (2006). Nepalese geographers meet in Pokhara: an introduction. In Subedi, B. P. Poudel P. C. and Poudel K.P. (eds.), Geography in Nepal: mountain environment and human activities. Kathmandu: Nepal Geographical Society Central Department on Geography Nepal Geography and NCCR North-South, pp. 1-9. 